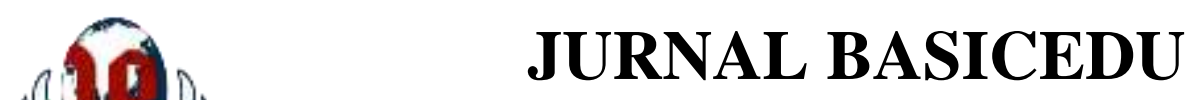

Volume 6 Nomor 1 Tahun 2022 Halaman 1155 - 1168

Research \& Learning in Elementary Education

https://jbasic.org/index.php/basicedu

\title{
Peran Orang Tua dalam Membentuk Karakter Anak Usia Dini di Taman Kanak-Kanak
}

\author{
Risky Ayu Permata ${ }^{凶}$ \\ Program Magister Pendidikan Agama Islam Konsentrasi PAUD Universitas Islam Negeri Sumatera Utara \\ E-mail: ayuphermatha@gmail.com
}

\begin{abstract}
Abstrak
Prinsip dalam pengasuhan orang yang berkaitan tentang pengembangan karakter, meliputi keteladanan, kebersamaan dalam merelisasikan nilai moral, sikap demokratis, jujur, kemampuan menghayati perkembangan anak dan kesatuan kata maupun tindakan. Tujuan penelitian ini untuk mengetahui peran orang tua dalam pembentukan karakter anak TK A di Khairin Islamic School, mengetahui permasalahan yang dihadapi orang tua dalam membentuk karakter anak dan menjelaskan dampak dari peran orang terhadap karakter anak usia. Hasil wawancara dengan guru kelompok A dan kelompok B sebagai guru kelas di KB. Guru kelas B menyatakan bahwa identifikasi anak didik dilakukan oleh para guru kelas dan guru pendamping. Guru pendamping ditugaskan mengidentifikasi anak yang mempunyai kebutuhan khusus untuk dilakukan parenting. Identifikasi kebutuhan belajar dilakukan dengan cara turun langsung ke lapangan, memberikan instrumen dan pengarahan. Berdasarkan data yang telah diamati oleh peneliti tentang peran orang tua dalam membentuk karakter anak didik sebagian besar orang tua menjawab sangat bagus 4 orang (80\%), yang menjawab biasa-biasa saja sebanyak 2 orang (20\%), dan yang menjawab kurang bagus tidak ada (0\%), jadi kesimpulan responden tetang melibatkan orang tua dalam membentuk karakter anak didik adalah sangat bagus.
\end{abstract}

Kata Kunci: Peran Orang Tua, Membentuk Karakter Anak.

\begin{abstract}
The principles in nurturing people related to character development include exemplary, togetherness in realizing moral values, democratic attitudes, honesty, the ability to appreciate children's development and unity of words and actions. The purpose of this study was to determine the role of parents in shaping the character of Kindergarten A children at Khairin Islamic School, to find out the problems faced by parents in shaping the character of their children and to explain the impact of the role of people on the character of young children. The results of interviews with teachers of group A and group B as classroom teachers in family planning. The class $B$ teacher stated that the identification of students was carried out by class teachers and accompanying teachers. The accompanying teacher is assigned to identify children who have special needs for parenting. Identification of learning needs is done by going directly to the field, providing instruments and guidance. Based on the data that has been observed by researchers about the role of parents in shaping the character of students, most of the parents answered very well 4 people (80\%), who answered mediocre as many as 2 people (20\%), and those who answered less well were none. (0\%), so the respondent's conclusion about involving parents in shaping the character of students is very good.
\end{abstract}

Keywords: the role of parents, shaping the character of children.

Copyright (c) 2022 Risky Ayu Permata

$\triangle$ Corresponding author :

Email : ayuphermatha@gmail.com

DOI : https://doi.org/10.31004/basicedu.v6i1.1969

ISSN 2580-3735 (Media Cetak)

ISSN 2580-1147 (Media Online)

Jurnal Basicedu Vol 6 No 1 Tahun 2022

p-ISSN 2580-3735 e-ISSN 2580-1147 


\section{PENDAHULUAN}

Anak merupakan anugerah yang telah Allah amanahkan kepada orang tua, dan orang tua berupaya melihat perkembangan dan tumbuh kembang anak-anaknya. Namun, setelah diamati dilapangan tidak sesuai dengan kenyataan pada umumnya. Pengetahuan intelektual yang sangat dibutuhkan pada anak yaitu mampu untuk bertahan hidup dan mengatur dirinya dan kepada orang lain. Pengetahuan atau keterampilan yang dimiliki seorang anak tidak menjamin dapat dipercaya orang lain jika tidak memiliki akhlak yang baik kepada sesamanya. Tanpa adanya akhlak, kesuksesan yang diraihnya akan tetap hancur karena tidak didasari oleh karakter atau akhlak yang baik dan kuat. Masih banyak hambatan-hambatan yang terjadi pada pengetahuan masyarakat tentang peran orang tua dalam membentuk karakter anak. Dalam pembentukan karakter seseorang terbentuk dari sikap, nilai dan kedewasaan yang didukung dan dibawa sejak lahir, keluarga maupun masyarakat sekitar. Kemampuan yang dimiliki anak seperti perasaan, pengetahuan dan fisik-motorik dapat membentuk karakter pada anak (Ta'rifin 2005).

Pentingnya peranan orang tua yang sering disebut dengan parenting. Parenting merupakan peran orang tua dalam menjalankan tugas dan tanggung jawabnya sebagai orang tua. Orang tua bukan hanya melahirkan dan mengasuh anak hingga mereka besar, melainkan harus mendidiknya (Ansori, A. 2018). Namun yang terjadi di masyarakat masih banyak orang tuayang tidak paham tentang bagaimana menjadi orang tua, bagaimana mendidik dengan penuh kasih sayang kepada anak. Dan banyak juga masyarakat yang hanya mengharapkan anaknya harus pintar, sukses, kaya, namun orang tua kurang memahami kesuksesan sesungguhnya yang sebaiknya dimiliki seorang anak dan bagaimana cara membuat seorang anak itu sukses (Akhyadi, A. S. 2018). Sugito (2008), mengungkapkan bahwa prinsip dalam pengasuhan orang yang berkaitan tentang pengembangan karakter, meliputi keteladanan, kebersamaan dalam merelisasikan nilai moral, sikap demokratis, jujur, kemampuan menghayati perkembangan anak dan kesatuan kata maupun tindakan. Pada tingkat menggunakan intensitas pada prinsip ini dapat meghasilkan kepercayaan dan kewibawaan orang tua di mata anak. Sehingga kepercayaan dan kewibawaan yang tinggi menghasilkan apresiasi anak pada orang tua (Yulianti 2010).

Penelitian mengenai peran orang tua dalam pendidikan anak telah banyak dilakukan sebelumnya, seperti penelitian menyimpulkan bahwa orang tua sangat berperan dalam membimbing anak-anaknya di rumah dengan panduan materi pelajaran sekolah yang disampaikan oleh guru di sekolah. Dalam pendidikan karakter, orang tua sangat perlu dalam memahami pendidikan karakter untuk menunjang keberhasilan pendidikan tersebut (Umar 2015). Sedangkan menurut penelitian, peran orang tua dalam menerapkan perilaku disiplin anak termasuk dalam kategori rendah jika tanpa dampingan guru di sekolah. Jika peran guru meningkat, maka akan terjadi pula peningkatan perilakku disiplin pada anak. Dengan begitu, penelitian tersebut menyimpulkan pembentukan karakter anak dapat dipengaruhi oleh guru dan orang tua (Suryono 2014).

Dari beberapa penelitian terdahulu, ditemukan beberapa penelitian mengenai peran orang tua dalam pendidikan karakter anak yang di anggap masih perlu pendampingan untuk anak-anak. Berdasarkan latar belakang tersebut, tujuan penelitian ini untuk mengetahui peran orang tua dalam pembentukan karakter anak TK A di Khairin Islamic School. Dengan mengetahui permasalahan yang dihadapi orang tua dalam membentuk karakter anak dapat menjelaskan dampak dari peran orang tua terhadap karakter anak usia dini.

\section{METODE}

Pendekatan penelitian ini menggunakan penelitian kualitatif analisis dengan studi kasus yang terjadi pada anak usia 4-5 tahun di TK Khairin Islamic School Jalan Tuamang. Inti dari permasalahan yang akan di pecahkan melalui rancangan studi kasus untuk mengidentifikasi masalah-masalah yang di hadapi orang tua 
1157 Peran Orang Tua dalam Membentuk Karakter Anak Usia Dini di Taman Kanak-Kanak - Risky Ayu Permata

DOI: https://doi.org/10.31004/basicedu.v6i1.1969

dalam mengasuh anak, dan dampak yang timbul dari tindakan yang telah diberikan. Subjek penelitian adalah orang tua murid di TK A Khairin Islamic School Medan. Peneliti melakukan serangkaian pengumpulan data secara intentsif tentang interaksi antara anak dan orang tua di lingkungan keluarga yang menjadi subjek penelitian.

Teknik pengumpulan data dilakukan dengan cara wawancara, obsevasi dan studi dokumentasi. Teknik analisis data dilakukan sebelum ke lapangan dan selama di lapangan (Miles, Huberman, and Saldana 2014). Ada 2 pengumpulan data yang dilakukan yaitu pengumpulan data primer dalam penelitian ini dilakukan melalui wawancara untuk menggali informasi dari informan yang dilakukan kepada orang tua murid, kepala sekolah dan guru di TK Khairin Islamic School Jalan Tuamang. Pengumpulan sekunder diperoleh melalui pencatatan dokumen-dokumen TK, Portofolio anak, serta dokumen lainnya untuk mendukung kegiatan pembelajaran di TK. Data sekunder digunakan sebagai data penunjang dan pelengkap dari data primer yang ada relevansinya dengan keperluan penelitian. Pengumpulan data dalam penelitian ini dilakukan dengan teknik observasi, wawancara, dan dokumentasi. Adapun lokasi penelitian ini dilaksanakan di TK Khairin Islamic School Jalan Tuamang.

\section{HASIL DAN PEMBAHASAN}

Hasil dari pengamatan lapangan yang dilakukan oleh penulis dari data lapangan terkumpul dari informan kemudian data tersebut direduksi dengan cara dipisahkan dan dirangkum, menyajikan dalam bentuk analisis uji pertanyaan penelitian, dirumuskan dan diambil kesimpulan. Pertanyaan penelitian yang sudah dianalisis kemudian penulis mendeskripsikan penelitian Peran Orang Tua dalam Membentuk Karakter Anak Didik Melalui BermainPeran. Hasilnya digambarkan sebagai berikut.

Persiapan Proses Peran Orang Tua dalam Membentuk Karakter Anak Didik Melalui Bermain Peran, dalam tahap ini persiapan yang dilaksnakan adalah Identifikasi kebutuhan dilakukan untuk menggali tentang sumber informasi anak, data keluarga, dan keinginan atau kebutuhan anak didik yang dapat terpenuhi melalui penyelenggaraan program membentuk karakter anak didik melalui bermaian peran. Hasil wawancara dengan guru kelompok A dan kelompok B sebagai guru kelas di KB. Guru kelas B menyatakan bahwa identifikasi anak didik dilakukan oleh para guru kelas dan guru pendamping. Guru pendamping ditugaskan mengidentifikasi anak yang mempunyai kebutuhan khusus untuk dilakukan parenting. Identifikasi kebutuhan belajar dilakukan dengan cara turun langsung ke lapangan, memberikan instrumen dan pengarahan (Indrianti 2020).

Berdasarkan data yang telah diamati oleh peneliti tentang peran orang tua dalam membentuk karakter anak didik sebagian besar orang tua menjawab sangat bagus 4 orang $(80 \%)$, yang menjawab biasa-biasa saja sebanyak 2 orang (20\%), dan yang menjawab kurang bagus tidak ada $(0 \%)$, jadi kesimpulan responden tetang melibatkan orang tua dalam membentuk karakter anak didik adalah sangat bagus. Sumber informasi merupakan yang pertama diidentifikasi. Sumber informasi merupakan seseorang atau kelompok yang memberikan informasi mengenai adanya suatu kegiatan atau aktivitas. Hasil wawancara dengan empat orang tua yang dijadikan sampel penelitian, memberikan informasi yang berbeda mengenai sumber infomasi dari para guru sebagai orang tua pertama yang diwawancara mengungkapkan bahwa ia mengetahui ada kegiatan keterlibatan orang tua dalam membentuk karakter anak didik dari guru kelas. Jk sebagai peserta kedua yang diwawancara mengungkapkan bahwa ia mengetahui tentang adanya keterlibatan orang tua dalam membentuk karakter anak didik dari guru pendamping. Peserta lainnya yaitu dari pernyataan dari FK mengatakan bahwa yang memberikan informasi tentang keterlibatan orang tua dalam membentuk karakter anak didik ini adalah teman. Peserta lain yang diwawancarai yaitu CC mengatakan mendapat informasi dari teman. Sesuai dengan hasil penelitian yang dilakukan TK A Khairin Islamic School Medan peran orang tua menjadi suatu sumber 
1158 Peran Orang Tua dalam Membentuk Karakter Anak Usia Dini di Taman Kanak-Kanak - Risky Ayu Permata

DOI: https://doi.org/10.31004/basicedu.v6i1.1969

yang sangat berpengaruh untuk perkembangan anak karena orang tua menjadi guru pertama bagi anak waupun anak akan bersekolah untuk proses perkembangan anak.

Orang tua memiliki peran terpenting dalam pembentukan karakter anak usia dini. Dariah (2018) mengatakan bahwa dalam pendidikan untuk membentuk sebuah karakter dapat berdampak bagi masa depannya sehingga masa depan anak ditentukan secara kepribadian dan karakter tergantung berdasarkan pengalaman yang diperoleh dari peran orang tua dalam mengasuh dan mendidiknya. Perilaku dan segala kelakuan yang diperbuat oleh orang tua sangat berpengaruh terhadapa pola pertumbuhan karakter anak berdasarkan penglihatannya karena anak bisa menirukan apa yang mereka lihat tanpa berfikir bahwa itu baik atau tidak, maka dari itu pengaruh orang tua dalam pembentukan karakter anak usia dini utamanya adalah pada lingkungan keluarga sebelum melihat lebih luas ke lingkungan masyarakat. Orang tua benar-benar memberikan dampak yang sangat berpengaruh terhadap pembentukan karakter anak usia dini sehingga perlu untuk benar-benar memberikan contoh dan perhatian secara khusus terhadap anaknya dalam upaya membentuk kepribadian dan karakter anak agar dapat bertumbuh dan berkembang secara positif untuk kedepanya. Sedangkan orang tua yang terlalu mengekang dan tidak memberikan kepedulian terhadap pertumbuhan anaknya akan sangat berdampak buruk untuk pembentukan karakter anak. Usia dini dalam hal ini adalah sebagai usia ideal untuk anak dalam menentukan kepribadian dan karakter anak untuk kedepanya.

Pendidikan karakter dikenalkan melalui pemodelan positif dari orang dewasa. Melalui ucapan, perilaku, pikiran, perasaan, dan tindakan yang di contohkan orang dewasa yang dilakukan secara terus menerus. Irmalia (2020) mengemukakan peran pendidik dan tenaga kependidikan antara lain, sebagai:

1. Figur teladan yang dicontoh anak dalam menumbuhkan berakhlak mulia, antara lain berbuat baik, santun, berprasangka baik, dan memiliki semangat dalam melakukan sesuatu.

2. Perancang yang merencanakan kegiatan bermakna dengan mengutamakan pengembangan karakter anak didiknya dalam penerapan proses pendidikan.

3. Komunikator yang secara aktif, terbuka, dan bijak mengkomunikasikan tentang isu-isu moral baik dan buruk dengan anak didiknya.

4. Cermin yang menangkap dan menampilkan kembali perasaan anak sehingga tumbuh pemahaman anak tentang yang dirasakannya dan rasa empati pada perasaan orang lain.

Penerapan pendidikan karakter memperhatikan juga adanya beberapa elemen pendukung antara lain berupa:

1. Buku acuan pendukung seperti buku-buku cerita bermuatan karakter, buku biografi berisi nilai karakter, dan lain-lain yang merupakan media belajar bagi penanaman pengetahuan dan perasaan tentang kebaikan.

2. Media bercerita berupa boneka tangan, bermain peran, dan alat permainan edukatif yang bisa dijadikan media pembentukan nilai karakter.

3. Media belajar berupa media yang tersedia dilingkungan lembaga PAUD dan dapat mendukung pendidikan karakter.

4. Motivator yang menciptakan suasana lingkungan yang menyenangkan, ramah, saling menghargai, dan sopan santun.

5. Katalisator yang menghubungkan antara lembaga PAUD dengan orang tua anak, khususnya dalam membangun kerjasama penerapan nilai-nilai karakter di rumah, di lembaga PAUD, dan di masyarakat sekitarnya. Sebagian orang tua peserta didik telah mengetahui, memahami dan melakukan nilai-nilai karakter yang dibelajarkan, seperti bekerja sama, kemandirian, disiplin, kejujuran, hormat dan santun, baik dan rendah hati.

Dalam hal mendidik anak untuk membentuk sebuah karakter pastinya harus berdasarkan berbagai pihak. Orang tua perlu untuk menyadari hal ini karena penanaman karakter pada anak usia dini untuk mengarah ke yang lebih baik akan menentukan masa depanya dalam hal berkarakter. Pembentukan karakter 


\section{Peran Orang Tua dalam Membentuk Karakter Anak Usia Dini di Taman Kanak-Kanak - Risky Ayu Permata \\ DOI: https://doi.org/10.31004/basicedu.v6i1.1969}

memiliki tujuan sebagai upaya untuk memperkuat bekal pondasi dasar utama dalam menyongsong kehidupan kedepanya sehingga dapat beradaptasi dengan lingkungannya. Anak usia dini secaara pemahaman memang belum memahami tentang moral, sehingga belum memiliki pengetahuan tentang arti perbedaan baik dan buruk. Maka dari itu peran penting orang tua sangat beras dalam membentuk kepribadian dan karakter anak sesuai dengan harapan meraka sehingga kedepanya anak tersebut sudah memiliki pondasi yang kokoh untuk bisa selalu menyesuaikan dengan lingkungannya terutama dalam memberikan pemahaman tentang moral. Akan tetapi tidak semua anak usia dini dapat melaksanakan pendidikan secara formal disekolah untuk mendapatkan pemahaman tentang sebuah karakter karena berdasarkan data ada sekitar 28 juta anak usia dini mengalami kendala dalam mendapatkan pelayanan pendidikan pra sekolah. Hal ini dipengaruhi oleh peran orang tua yang beranggapan bahwa pendidikan pra sekolah adalah hal yang tidak penting bahkan mereka beranggapan membuang waktu dan membuang biaya karena keterbatasan dana untuk pembayaranya sehingga orang tua seperti ini pastinya akan sangat kesulitan dalam memahami karakter dan membentuk anak secara pribadi dengan lingkungan keluarganya (Sari and Nofriadi 2019).

Banyak orang tua yang tidak peduli dengan pendidikan anak usia dini dalam upaya membetuk karakter anak dan mereka juga tidak menyadari bahwa pembentukan karakter anak dapat dilakukan dengan salah satunya adalah bermain bersama. Melalui pendidikan dengan kombinasi bermain bersama anak akan dengan sendirinya mampu belajar tanpa disadari untuk mulai menyesuaikan dengan lingkungan sekitarnya. Dunia anak adalah dunia bermain, maka dari itu merupakan sebuah kebutuhan pokok buat anak adalah dengan bermain. Oleh karena itu orang tua memiliki peran penting pada anak untuk selalu berinovasi dengan selalu berkegiatan bermain bersama sehingga dengan seiring berjalanya waktu anak dapat memahami berbagai hal dengan memperlihatkan karakternya dan dengan konsep bermain dapat dijadikan sebagai kegiatan yang memberikan fasilitas untuk anak dalam mengasah potensi yang dimilikinya. Orang tua dalam hal ini tidak sekedar memperkenalkan berbagai permainan saja teapi juga disertai dengan selalu berupaya untuk dapat meningkatkan ketrampilan anak denngan berbagai pengetahuan baru sebagai seorang pendidik utama dalam lingkungan keluarga. Perang yang dilakukan orang tua sebagai bentuk dalam memberikan pendidikan karakter pada anak usia dini juga dapat dilakukan dengan memberikan metode rangsangan-rangsangan dengan memberikan permainan yang bersifat bertahap seuai dengan usia dan perkembangan anak. Karena dengan bermain yang merupakan bentuk kebahagian anak adalah sebagai jembatan untuk menyisipkan pembelajaran pada anak tentang hal-hal baru. Kegiatan bermain merupakan suatu aktivitas yang membantu anak mencapai perkembangan yang utuh secara fisik, intelektual, sosial, moral, dan emosional. Pendidikan karakter harus berkaitan dengan optimalisasi fungsi otak kanan. Orang tua dalam hal ini juga perlu untuk berhati-hati yaitu jangan sampai memberikan bentuk permainan dan pembelajaran tentang moral yang buruk, memberikan penekanan pada otak kiri untuk melawan dan pemberitahuan yang tidak tuntas bahkan dalam kondisi bercanda, karena anak usia dini belum dapat membedakan antara konteks yang bercanda atau serius. Jika orang tua dapat memberikan contoh untuk anak melalui perilaku yang mengedepankan kebaikan dalam berbagai hal seperti etika, harga diri, tanggung jawab, toleransi, dan kedisiplinan maka anak akan selau mengingat sampai usia dewasa dengan bekas yang sudah tertanam. Tantang berat memang sangat menanti orang tua untuk memberikan pendidikan karakter sebagai bentuk dalam mendidik anak sesuai dengan kemauannya. Pembentukan karakter bukan sebuah hal yang mudah untuk orang tua karena anak juga memiliki segala kekurangan dan kelebihan sehingga hasil dari pembentukan karakter hanya bisa diharapkan untuk memberikan dampak yang lebih baik secara berkelanjutan untuk anak terlebih pada etika dan moralnya (Erzad 2018).

Proses pembentukan karakter pada anak usia dini yang dijalankan oleh orang tua di dalam lingkungan keluarga atau di rumah memiliki kewajiban untuk selalu menilai perkemangan akan dengan memantau secara langsung. Hal ini perlu dilakukan secara berkelanjutan sebagai bentuk dan wujud kepedulian orang tua terhadap pembentukan karakter anak. Orang tua perlu memahami berbagai hal yang harus diperhatikan dalam 
melaksanakan penilaian terhadap perkembangan karakter anak, seperti kedisiplinan, moral, etika dan aktivitas dari bangun pagi sampai tidur malam. Hal-hal kecil juga perlu untuk diperhatikan seperti berdoa dan berjabat tangan sebelum dan pulang sekolah. Karena dengan kepedulian anak terhadap hal hal kecil inilah membuat anak akan dengan tanpa disadari berdampak terhadap hal yang lebih besar dengan lebih berhati-hati. Selain itu dengan pola dan tingkah laku anak yang sudah selalu berbuat baik maka peran orang tua selanjutnya adalah dengan memberikan sebuah reward atau hadiah berupa pujian sampai barang atau memenuhi janjinya kepada anak dan bisa juga memenuhi keinginan anak. Tetapi bagi anak yang belum bisa melakukan pembiasaan berbuat baik atau masih sering melakukan aktivitas di luar aturan, maka perlu langkah persuasif agar bisa melakukan pembiasaan yang positif. Orangtua memiliki peranan yang sangat besar dalam membangun karakter anak. Waktu anak di rumah lebih banyak dibandingkan di sekolah. Apalagi, sekolah merupakan lingkungan yang dikendalikan. Anak bisa saja hanya takut pada aturan yang dibuat. Sementara, rumah merupakan lingkungan sebenarnya yang dihadapi anak. Rumah adalah tempat pertama anak berkomunikasi dan bersosialisasi dengan lingkungannya (Sari and Nofriadi 2019).

Dengan adanya peran orang tuan untuk membentuk karakter pada anak sangat penting perannya karena sebagai wujud untuk memberikan harapan pada anak dalam bentuk kasih sayang berupa kepedulian yang mengarah pada pedadogi ideal dan spiritual anak lebih diperhatikan. Karena selama ini banyak anak yang mulai dibiasakan dengan gadget dan orang tua juga terlalu sibuk. Selama ini juga manusia seperti tunduk dengan hukum teknologi yang artinya semua mengandalkan teknologi tanpa memperhatikan dampak buruk dalam masa depanya sehingga kebebasan manusia sangat memiliki kemungkinan untuk menghayati bentuk kerakter anak yang sedang berkembang. Sebagai orang tua tidak semata-mata taat pada aturan alamiah. Melainkan kebebasan itu dihayati dalam tata aturan yang sifatnya mengatasi individu, dalam tata aturan nilainilai moral. Pedoman nilai merupakan kriteria yang menentukan kualitas tindakan manusia di dunia. Dalam proses pembentukan pengetahuan,melalui berbagai pola asuh yang disampaikan oleh seorang ibu sebagai pendidik pertama sangatlah penting. Pendidikan dalam keluarga sangat berperan dalam mengembangkan watak, kepribadian, nilai-nilai budaya, nilai-nilai keagamaan dan moral, serta keterampilan sederhana. Dalam konteks ini proses sosialisasi dan enkulturasi terjadi secara berkelanjutan. Hal ini bertujuan untuk membimbing anak agar menjadi manusia yang beriman, bertaqwa, berakhlak mulia, tangguh, mandiri, inovatif, kreatif, beretos kerja, setia kawan, peduli akan lingkungan, dan lain sebagainya (Santika 2018).

Pembentukan karakter dan kepribadian anak usia dini memang sebuah tanggung jawab dari orang tua yang salah satunya adalah dalam hal pembelajaran bahasa. Hal ini sangat rawan untuk anak karena hanya dengan mendengarkan anak mampu mengingat kata apa yang pernah didengarkan dan tidak mengetahui kapan kata tersebu pantas untuk dikeluarkan. Dalam hal ini orang tua harus lebih mengarahkan anaknya untuk memberikan nasehat atau informasi bahwa penggunaan kata harus disesuaikan dengan situasi dan kondisi sehingga sebisa mungkin anak akan tetap memiliki karakter yang baik di lingkungan keluarga dan sekitarnya. Dengan ini tentunya masih banyak contoh lain yang bisa dikembangkan, yaitu pembiasaan-pembiasaan lainnya sesuai lingkungan budaya masing-masing, misal membiasakan menghargai hasil karya anak walau bagaimanapun bentuknya dan tidak membandingkan hasil karya anak dengan hasil karya saudara-saudaranya sendiri. Keluarga dapat berperan sebagai fondasi dasar untuk memulai langkah-langkah pembudayaan karakter melalui pembiasaan bersikap dan berperilaku sesuai dengan karakter yang diharapkan. Pembiasaan yang disertai dengan teladan dan diperkuat dengan penanaman nilai. Banyak anggapan bahwa pendidikan baru bisa dimulai setelah usia sekolah dasar, ternyata tidak benar, bahkan pendidikan yang dimulai usia taman kanak-kanakpun sebenarnya sudah terlambat.pertumbuhan sel jaringan otak pada anak usia 0-4 tahun mencapai 50\%. Artinya bila pada usia tersebut otak anak tidak mendapatkan rangsangan yang maksimal maka segala tumbuh kembang anak baik fisik maupun mental tidak akan berkembang secara optimal (Andhika 2021). 
Karakter anak memiliki peran penting dalam menentukan masa depan anak, sehingga peran orang tua yang mendidik di dalam rumah dapat dilakukan sejak dalam kandungan, kehidupan anak dimulai saat sel telur dibuahi oleh sel sperma. Dari satu sel yang dibuahi, membelah secara berulang menghasilkan ribuan, jutaan, bahkan milyaran sel. Dari sel yang sama bentuk dan fungsinya berkembang menjadi sel yang bersifat khusus seperti sel syaraf, sel otot, sel darah, sel tulang. Sel-sel tersebut membentuk jaringan, seperti jaringan syaraf, jaringan otot, jaringan darah, jaringan epitel, dan jaringan tulang. Jaringan membentuk organ, seperti otak, jantung, mata, telinga, tangan dan kaki. Perkembangan organ tubuh yang sangat pesat saat prenatal adalah perkembangan otak. Sel-sel syaraf otak terbentuk sejak usia kehamilan tiga bulan pertama. Oleh karena itu bayi usia sekitar 2-3 bulan, ukuran kepala jauh lebih besar dari organ lainnya. Secara biologis kecerdasan sangat dipengaruhi oleh kinerja otak. Kemampuan kinerja otak sangat ditentukan oleh jumlah sel syaraf dan jumlah hubungan antar sel syaraf otak. Pertumbuhan dan perkembangan sel syaraf otak saat prenatal, selain dipengaruhi oleh faktor genetis juga dipengaruhi oleh faktor makanan. Makanan yang bergizi dan seimbang diperlukan tubuh agar sel syaraf otak dapat tumbuh secara optimal. Pada saat masih dalam kandungan, ibu hamil harus mengkonsumsi makanan yang bergizi, menghindari terlalu banyak kafein, merokok, minuman keras, obat-obatan yang dapat menghambat pertumbuhan sel syaraf otak pada janinnya. Kesehatan badan dan imunitas sangat besar pengaruhnya terhadap perkembangan kecerdasan anak. Tubuh anak yang sehat berkembang dengan baik termasuk otaknya. Air susu ibu amat penting bagi kesehatan dan imunitas anak. ASI mengandung zat-zat makanan yang sesuai dengan kondisi saluran. pencernaan anak. ASI mengandung cairan kekuningan yang disebut kolostrum. Kolostrom mengandung antibody, suatu zat yang berguna bagi tubuh untuk mempertahankan diri dari penyakit (imunitas). Jadi bila bayi tumbuh sehat pada tahun-tahun pertama kehidupannya maka ini akan menambah jumlah sel-sel syaraf otaknya dimana pertumbuhan ini menambah perkembangan kecerdasan bayi tersebut. Setelah anak dilahirkan, tahun-tahun awal kehidupan merupakan saat yang paling kritis bagi pertumbuhan dan perkembangan otak (Irmalia 2020).

Para ahli berpendapat bahwa peranan orang tua begitu besar dalam membantu anak agar siap memasuki gerbang kehidupan mereka. Maka perlu adanya partisipasi orang tua terhadap pendidikan anak usia dini agar anak memiliki kesiapan dalam memasuki gerbang kehidupan tersebut. Orang tua adalah pendidik pertama dan utama dalam pembentukan karakter anak.Pelaksanaan suatu program pendidikan budi pekerti anak usia dini tidak akan berjalan dengan lancar dan baik, jika tidak ada peran dari orang tuanya. Karena pendidikan anak sebenarnya merupakan tanggung jawab penuh dari orang tuanya. Tanggung jawab ini diwujudkan dalam keterlibatan langsung orang tua dalam pendidikan anaknya dari sejak lahir.partisipasi orang tua dalam PAUD dalam hal masa peka, masa egosentris, masa meniru, masa berkelompok, masa bereksplorasi, dimana dalam masa itu perkembangan optimal harus dilakukan pada anak usia dini.Untuk itu menurut (Sabartiningsih, Muzakki, and Durtam 2018) sebaiknya orang tua atau pendidik, perlu:

1. Memberi kesempatan dan menunjukkan permainan serta alat permainan tertentu yang dapat memicu munculnya masa peka/menumbuh kembangkan potensi, dari alat-alat bermain ini, orang tua/pengasuh memberi permaianan yang menimbulkan anakanak ingin tahu terus menerus dan disinilah palatihan budi pekerti disalurkan melalui permainan dengan kerjasama dengan teman-temannya, berbagi dengan teman-temannya, ini penerapan dari latihan sabar, kasih sayang sesama teman, narima, bila permainan tidak sesuai dengan keinginannya dan rela, bila mainannya direbut oleh temannya.

2. Memahami bahwa anak masih berada dalam masa egosentris yang ditandai dengan seolah-olah dialah yang paling benar, keinginannya harus selalu dituruti dan sikap mau menang sendiri, dan sikap dari orang tua dalam memasuki masa egosentris dengan memberi pengertian secara bertahap pada anak agar dapat menjadi mahluk sosial yang baik, dengan bentuk kasih sayang, cinta kasih, contoh-contoh cerita, diberi reward bila anak mau menundukkan egonya, karena kebiasaan yang baik, anak akan memahami nasehat orang tuanya. 
1162 Peran Orang Tua dalam Membentuk Karakter Anak Usia Dini di Taman Kanak-Kanak - Risky Ayu Permata

DOI: https://doi.org/10.31004/basicedu.v6i1.1969

3. Masa meniru pada anak usia dini sangat kuat, tidak hanya meniru pada orang-orang disekitarnya tetapi juga pada tokoh-tokoh khayal yang sering ditampilkan ditelevisi, pada saat itu orang tua atau pengasuh harus menjadi tokoh panutan bagi anak dalam berperilaku, anak bisa meniru perilaku mahluk lain yang punya kebiasaan baik misal, meniru perilaku anjing dirumah yang selalu taat pada tuannya, sehingga tuannya selalu memberi makan yang sesuai seleranya.

4. Masa berkelompok, biarkan anak bermain diluar bersama temannya, jangan terlalu membatasi anak,agar anak bisa bersosialisasi dan beradaptasi sesuai dengan perilaku lingkungan sosialnya, ini adalah pendidikan budi pekerti untuk kasih sayang sesama hidup.

5. Pentingnya eksplorasi bagi anak, biarkan anak memanfaatkan benda benda yang ada disekitarnya dan biarkan dia melakukan trial and error, karena anak adalah penjelajah yang ulung, orang tua jangan membatasi terlalu kaku, agar pendidikan budi pekerti untuk menanamkan perilaku sabar dalam mengeksplorasi keinginan anak. 5. Disarankan tidak boleh memarahi anak bila dia membangkang, karena bagaimanapun juga merupakan masa yang dilalui anak, bila terjadi pembangkangan, sebaiknya diberi waktu pendinginan (cooling down), misalnya berupa penghentian aktivitas anak dan membiarkan anak sendiri berada didalam kamarnya/ sudut ruangan, baru beberapa waktu kemudian anak diberi nasehat tentang mengapa anak harus melakukan itu semua, dinasehati dengan penuh kasih sayang.

Pada kenyataannya masih terdapat sebagian besar orang tua dan guru belum memahami akan potensi luar biasa yang dimiliki anak usia dini. Keterbatasan pengetahuan dan informasi yang dimiliki orang tua dan guru menyebabkan potensi yang dimiliki anak tidak berkembang optimal. Para ahli berpendapat bahwa peranan orang tua begitu besar dalam membantu anak agar siap memasuki gerbang kehidupan mereka. Ketika memasuki gerbang tersebut, mereka masuk dalam dunia independen yang sudah seharusnya terlepas dari orang tua, dimana keputusan hidup mereka sudah harus dapat dilakukan sendiri. Disinilah peran orang tua sudah berkurang, dan melihat hasil didikan mereka. Maka perlu adanya partisipasi orang tua terhadap pendidikan anak usia dini agar anak memiliki kesiapan dalam memasuki gerbang kehidupan tersebut. Pelaksanaan suatu program pendidikan anak usia dini tidak akan berjalan dengan lancar dan baik, jika tidak ada peran dari orang tua muridnya. Karena pendidikan anak sebenarnya merupakan tanggung jawab penuh dari orang tuanya. Tanggung jawab ini diwujudkan dalam keterlibatan langsung orang tua dalam pendidikan anaknyadari sejak lahir (Astuti 2019).

Pembentukan karakter anak tidaklah lahir begitu saja, ada proses yang dilewatinya sehingga proses tersebut pun menjadi karakter yang melekat dalam diri seorang anak. Mulai dari anak tersebut lahir dan tumbuh berkembang menjadi dewasa di lingkungan keluarga, bergaul dengan teman-teman dalam kelompok permainan, sekolah, sampai dengan masyarakat. Sebagai orang tua, tanpa disadari, sikap orang tua yang negatif pada anaknya pun justru akan menjatuhkan anak tersebut. Keluarga sebagai sebuah lembaga pendidikan yang pertama dan utama. Keluarga diharapkan senantiasa berusaha menyediakan kebutuhan, baik biologis maupun psikologis bagi anak, serta merawat dan mendidiknya. Keluarga diharapkan mampu menghasilkan anak-anak yang dapat tumbuh menjadi pribadi, serta mampu hidup di tengah-tengah masyarakat. Sekaligus dapat menerima dan mewarisi nilai-nilai kehidupan dan kebudayaan. (M. Syahran Jailani, 2014). Menurut Selo Soemarjan, keluarga adalah sebagai kelompok inti, sebab keluarga adalah masyarakat pendidikan pertama dan bersifat alamiah. Dalam keluarga, anak dipersiapkan untuk menjalani tingkatan-tingkatan perkembangannya sebagai bekal ketika memasuki dunia orang dewasa, bahasa, adat istiadat dan seluruh isi kebudayaan, seharusnya menjadi tugas yang dikerjakan keluarga dan masyarakat di dalam mempertahankan kehidupan oleh keluarga (Hasanah 2017).

Orang tua sangat berperan dalam pembentukan karakter anak usia dini. Namun pada kenyatannya banyak orang tua yang tidak begitu memperhatikan hal tersebut. Mereka menganggap bahwa ketika anak sudah sekolah, maka tanggung jawab penuh untuk mendidik anak-anak mereka dibebankan sepenuhnya pada guru. Sehingga perlu adanya pemahaman lebih tentang upaya membentuk karakter anak sejak usia dini yang 


\section{Peran Orang Tua dalam Membentuk Karakter Anak Usia Dini di Taman Kanak-Kanak - Risky Ayu Permata \\ DOI: https://doi.org/10.31004/basicedu.v6i1.1969}

bisa dilakukan oleh orang tua. Berdasarkan pendapat ahli ini, maka untuk melihat sejauh mana perlakuan dan peranan orang tua dalam gaya pengasuhannya berupa kontrol terhadap perilaku dan nilai kehidupanyang mampu mempengaruhi sikap dan tingkah laku anak-anaknya dimasa depan. Pada umunya sebagian orang enggan untuk memikirkan suatu perubahan, mereka berpikir bahwa sudah ada orang yang berwenang, pintar yang telah ditugaskan. Pola pikir yang tidak baik ini dipelihara oleh orang yang tidak mau berpikir. Orang bersikap tidak berdaya, berdiam diri, protes, menggantungkan harapan datangnya inspirasi cerdas dari orang pintar dan para pemimpin. Masalah yang dihadapi seharusnya mendorong banyak ide, gagasan, dan solusi kreatif. Pola bimbingan atau pola asuh orangtua pada umumnya sangat mempengaruhi kepribadian seorang anak. Pola bimbingan orangtua dalam mendidik anak dapat terlihat pada kemandirian, mengenali dan memahami dirinya, mampu membuat pilihan dan dapat merencanakan masa depannya. Jadi Hal-hal yang perlu dilakukan orang tua dalam membimbing anaknya adalah membantu anak-anak memahami posisi dan peranannya sesuai dengan jenis kelaminya, agar mampu saling menghormati dan saling tolong-menolong dalam melaksanakan perbuatan yang baik, Membantu anak-anak mengenal dan memahami nilai-nilai yang mengatur kehidupan berkeluarga, bertetangga, bermasyarakat, dan mampu melaksanakannya sesuai dengan norma yang berlaku, Mendorong anak-anak untuk mencari ilmu dunia dan ilmu agama, agar mampu merealisasikan dirinya sebagai individu dan bagian dari masyarakat, Membantu anak-anak memasuki kehidupan bermasyarakat setahap demi setahap melepaskan diri dari ketergantungan pada orang tua dan orang dewasa lainnya, serta mampu bertanggung jawab atas sikap dan perilakunya, serta membantu dan memberi kesempatan serta mendorong anak-anak mengerjakan sendiri dan berpartisipasi dalam melaksanakan kegiatan agama, didalam keluarga dan masyarakat (Latifah 2020).

Pola asuh orang tua pada anak usia dini akan membentuk karakter ada anak, karenanya orang hendaknya memberikan stimulasi yang cukup bagi anak usia dini jikalau itu kurang akan mengakibatkan kemampuan sosialisi, bahasa, motorik halus dan kasar menjadi terlambat, maka dari itu lingkungan yang menunjang akan mendukung tumbuh kembang pada anak usia dini, proses pertumbuhan dan perkembangan seorang anak sangat pesat dan dapat berpengaruh bagi kehidupan selanjutnya. Anak pada masanya pembentukan biasanya akan di pengaruhi oleh faktor gentik dan lingkungan dalam membentuk karakter pada anak. Banyak sekali problematika peran penting pola asuh orang tua bagi keberlangsungannya perkembangan anak usia dini, disamping kesibukan dari orang tua adapula orang tua yang belum memahami betapa pentingnya keterlibatan rang tua dalam mengasuh anak, hingga akhirnya mengakibatkan beberapa masalah bagi perkembangan anak di berbagai aspek. Dalam penelitian sebelumnya yang dilakukan oleh Uswatun Hasanah dengan judul penelitian Pola Asuh Orang tua dalam Membantuk Karakter Anak, yang mana menyebutkan bahwa karakter seseorang berkembang berdasarkan potensi yang dibawanya sejak dari lahir, akan tetapi semakin berkembangnya seorang apalagi anak usia dini, perkmenbangan anak juga melibatkan peran dari orang tua yang mana dibutuhkan dalam membentuk perkembangan dari karakter seorang anak, bahwa pola asuh dari orang tua dapat mempengaruhi dan membentuk pribadi dari seorang anak secara signifikan (Adpriyadi and Sudarto 2020).

Peran penting orang tua dalam pembentukan karakter anak perlu diperhatikan sebab pola asuh memiliki hubungan erat dengan sebuah keberhasilan Pendidikan anak, akantetapi disisi lain juga mempunyai hubungan erat dengan kenakalan remaja. Perkembangan pada anak usia dini dapat diartikan pula sebagai proses tranmisi dari konstitusi psiko-fisik yang herediter, dirangsang oleh faktor-faktor lingkungan yang menguntungkan, dalam perwujudan proses aktif-menjadi secara kontinu. sebagai bentuk perilaku kolektif seorang anak dengan perilaku kerjasama dengan orang lain. Pada proses perkembangannya anak usia dini lingkungan menjadi faktor yang sangat penting setelah faktor hereditas atau keturunan, sebab tanpa adanya dukungan dari faktor lingkungan maka proses perkembangan dalam mewujudkan potensi hereditas atau keturunan menjadi kemampuan yang tidak akan terjadi. Dalam pengertiannya lingkungan berarti kondisi yang berada disekitar kita, pada pendidikan sendiri arti dari lingkungan itu sendiri sangatlah luas, yang mana kondisi sesuatu berada 


\section{Peran Orang Tua dalam Membentuk Karakter Anak Usia Dini di Taman Kanak-Kanak - Risky Ayu Permata \\ DOI: https://doi.org/10.31004/basicedu.v6i1.1969}

di luar diri anak usia dini. Perkembangan anak usia dini juga berpengaruh dari beberapa faktor lingkungan yang mempengaruhinya, diantaranya faktor-faktor tersebut adalah sebagai berikut (Astuti 2019).

Pada hakikatnya, belajar harus berlangsung sepanjang hayat, dan dilakukan sejak usia dini. Dalam kerangka inilah pentingnya PAUD untuk mengembangkan berbagai potensi anak sejak dini, terutama pada usia emas (the golden age), yaitu pendidikan yang ditunjukan bagi anak sejak lahir hingga usia enam tahun. Oleh karena itulah, mereka yang membangun dan mendirikan rumah tentunya bertanggung jawab atas terbentuknya rumah yang indah dan asri agar dapat menjadi tempat berteduh yang nyaman untuk dirinya, pasangan hidupnya, dan anak-anaknya. Demikian halnya dalam mendidik anak. Apabila anak arahkan sesuai kapasitas, potensi, dan perkembangan serta tahap-tahapan yang akan dilaluinya, maka anak akan menjadi penyejuk sanubari dan menyenangkan bila dipandang mata. Anak merupakan amanah yang diberikan Tuhan kepada orang tua yang harus dijaga dan dipelihara. Jika anak-anak dibiarkan hidup tanpa perhatian dan tidak diarahkan sebaik-baiknya, ataupun dibentuk dengan kehendak orang tuanya yang tidak sesuai dengan keinginan dan kehendak Pemberi Amanah, maka tentulah orang tua akan diminta pertanggungjawabannya. Di sinilah PAUD yang menjadi fase pendidikan prasekolah memberikan warna positif bagi pendidikan anak yang memberikan dorongan, arahan, bimbingan, dan jalan terbaik bagi penggalian dan perkembangan potensi, penataan moral, dan pelecutan spirit kompetisi yang besar (Irmalia 2020).

Pada dasarnya, untuk mencapai perkembangan yang optimal anak perlu mendapatkan stimulasi dari lingkungan. Pemberian stimulasi harus dilakukan pada saat yang tepat dengan jumlah yang memadai. Untuk itu, orang tua harus tahu benar tentang keadaan anak serta peka terhadap kebutuhannya. Kesempatan bermain dengan dengan anak-anak lainnya menjadikan mereka memiliki banyak kesempatan untuk bekerjasama dan memahami perspektif serta perasaan orang lain. Jika terjadi konflik, mereka akan belajar bagaimana mengatasi perasaan frustasi, marah, dan kecewa. Pengalaman mengikuti pendidikan prasekolah sangat bernilai, khususnya bagi anak yang berasal dari keluarga kecil. Karena hal itu dapat membantu anak belajar bagaimana sebaiknya menjalin hubungan dengan orang lain. Para guru di pendidikan prasekolah yang baik biasanya mencoba untuk mengembangkan kemampuan kognitif anak dalam berbagai cara. Mereka memberikan berbagai macam pengalaman kepada anak sehingga memungkinkan berlangsungnya proses bermain sambil belajar (Andhika 2021). Pembentukan karakter berkaitan langsung dengan tahapan perkembangannya. Tahapan tersebut terbagi dalam tiga tahapan yaitu tahapankarakter lahiriyah (karakter anak-anak), tahapan karakter berkesadaran (karakter remaja) dan tahapan kontrol internal atas karakter (karakter dewasa). Pada tahapan lahiriyah metoda yang digunakan adalah pengarahan, pembiasaan, keteladanan, penguatan (imbalan) dan pelemahan (hukuman) serta indoktrinasi. Sedangkan pada tahapan perilaku berkesadaran, metoda yang digunakan adalah penanaman nilai melalui dialog yang bertujuan meyakinkan, pembimbingan bukan instruksi dan pelibatan bukan pemaksaan. Dan pada tahapan kontrol internal atas karakter maka metoda yang diterapkan adalah perumusan visi dan misi hidup pribadi, serta penguatan akan tanggungjawab langsung kepada Allah. Tahapan diatas lebih didasarkan pada sifat daripada umur.

Pembiasaan merupakan bagian penting dalam tahapan penalaran prakonvensional dimana anak mulamula mengembangkan keterampilan hidupnya lebih banyak bergantung pada faktor eksternal. Oleh karena itu, peran orang tua dan guru dalam mengembangkan pembiasaan prilaku baik melalui contoh dan tindakan. Sejalan dengan pertumbuhan dan perkembangan anak, tahapan ini akan berangsur angsur menuju ke tahap konvensional dimana anak mulai mengembangkan nilai pribadi dan menjadikan nilai-nilai tertentu sebagai pemandu prilakunya.Dalam usaha memberikan pendidikan dan membantu perkembangan anak usia dini, selain pengembangan kecerdasan dan keterampilan, perlu juga sejak dini ditanamkan kebiasaankebiasaan yang positif. Pendidikan dengan mengajarkan dan pembiasaan adalah pilar terkuat untuk pendidikan anak usia dini, dan metode paling efektif dalam membentuk iman anak dan meluruskan akhlaknya, sebab metode ini berlandasakan pada pengikutsertaan.pembiasaan anak sejak dini adalah paling menjamin 


\section{Peran Orang Tua dalam Membentuk Karakter Anak Usia Dini di Taman Kanak-Kanak - Risky Ayu Permata \\ DOI: https://doi.org/10.31004/basicedu.v6i1.1969}

untuk mendatangkan hasil positif, sedangkan mendidik dan melatih setelah dewasa sangat sukar untuk mencapai kesempurnaan.

Kebiasaan merupakan bentuk tingkah laku yang tetap dari usaha menyesuaikan diri terhadap lingkungan yang mengandung unsur afektif perasaan. Kebiasaan diperoleh dengan jalan latihan, peniruan dan ulangan secara terus menerus, semula semua latihan, peniruan dan ulangan itu berlangsung secara disadari, lambat laun menjadi kurang disadari untuk selanjutnya menjadi otomatis mekanistis, tidak disadari. Pembiasaan merupakan metode yang sangat tepat dilakukan dalam pendidikan pada usia anak-anak karena kecenderungan dan naluri anak-anak dalam pengajaran dan pembiasaan adalah sangat besar di banding usia lainnya. Dan merupakan pilar terkuat dalam pendidikan dan metode paling efektif dalam membentuk iman anak serta meluruskan akhlaknya.Karena sangat pentingnya pembiasaan di dalam membentuk tingkah laku anak, mengurangi perilaku yang buruk (karena tidak diperlakukan) maka akan muncul pola perilaku baru yang relative menetap dan otomatis maka, membiasakan anak untuk selalu berdoa ketika sebelum, selama dan sesudah melakukan suatu aktivitas adalah hal yang sangat dianjurkan (Nuraini and Mahmud 2020).

Terbentuknya Karakter seorang anak terlihat pada saat anak berusia 3 hingga 10 tahun. Tugas dari orangtualah untuk menentukan akan seperti apa yang masuk ke dalam pikirannya, sehingga akan membentuk karakter anak yang berkualitas. Karakter adalah sesuatu yang dibentuk, dikonstruksi, seiring dengan berjalannya waktu dan semakin berkembangnya seorang anak. Pada dasarnya anak itu ibarat kanvas putih bersih. Orang-orang dewasa disekitarnya yang membentuk lempung itu. Akan berbentuk apa lempung itu, hal itu tergantung pada orangtua yang membentuknya. Ini berkaitan dengan bagaimana dan cara yang harus dilakukan agar anak dari tingkat dasar hingga tingkat tinggi dapat menginternalisasi, menjalankan, dan terus menjadikan pegangan dalam kehidupan. Ada 18 karakter yang dapat ditanamkan dalam kehidupan anak-anak. Diantaranya; religius, jujur, toleransi, disiplin, kerja keras, kreatif, mandiri, demokratis, rasa ingin tahu, semangat kebangsaan, cinta tanah Air, menghargai prestasi, bersahabat/komunikatif, cinta damai, gemar membaca, peduli lingkungan, peduli sosial, dan tanggung jawab (Pertiwi 2021).

Pendidikan agama juga sangat penting dalam lingkungan pendidikan seorang anak. Pendidikan agama dapat berfungsi sebagai kontrol internal pada diri sang anak. Lingkungan keluarga harus bisa memberikan contoh perilaku yang baik kepada sang anak. Ubah lingkungan di mana sang anak itu tumbuh jadi lingkungan yang memberi teladan baik. Tempatkan ia dalam lingkungan yang memunculkan sifat-sifat baik dalam dirinya. Lingkungan inilah yang terutama membentuk lempung (anak) itu. Membangun karakter diperlukan juga semacam reward and punishment untuk sang anak, terutama disekolah. Jika ia berlaku baik, beri semacam "hadiah" apa pun bentuknya, entah itu pujian atau apa pun. Jika ia berlaku buruk, beri juga ia hukuman. Lingkungan dan reward and punishment ini nantinya akan menjadi semacam kontrol eksternal (sosial) pada diri sang anak, yang lazimnya jauh lebih efektif ketimbang sekadar kontrol internal dalam membentuk karakter baik anak.Seorang anak pada usia dibawah 10 tahun belum mempunyai fondasi yang kuat dalam prinsip hidup, cara berpikir, dan tingkah laku. Artinya, semua hal yang dilihat, didengar, dan dirasakan olehnya dari lingkungan selama masa pertumbuhan tersebut akan diserap semuanya oleh pikiran dan dijadikan sebagai dasar atau prinsip dalam hidupnya. Adalah tugas orang tua untuk memilah dan menentukan, input-input mana saja yang perlu dimasukkan,dan mana yang perlu dihindarkan. Menonton televisi misalnya, tidak semua acara itu bagus. Demikian juga dengan membaca majalah, menonton film, mendengarkan radio, dan sebagainya (Erzad 2018).

Seorang anak perlu figur seorang tokoh yang dikagumi, yang akan ditiru di dalam tindakan sehariharinya. Pilihan utamanya biasanya akan jatuh pada orang tua. Dan seorang anak akan lebih percaya pada apa yang dilihat daripada apa yang dikatakan orang tua. Jadi saat orang tua mengatakan satu nasehat, misalnya jangan tidur malam-malam, tapi orang tuanya sendiri selalu bekerja sampai larut malam, jelas ini bukan cara mendidik yang baik. Ajarkan sesuatu melalui contoh, dengan tindakan kita sendiri, akan membuat anak meniru dan mengembangkannya menjadi suatu kebiasaan dan karakter di dalam pertumbuhannya. 
Pembentukan karakter tangguh pada anak, didasari pada Apa yang akan anda lakukan sebagai orang tua apabila anak anda merengek-rengek, bahkan menangis minta dibelikan sebuah mainan. Ada dua jenis jawaban yang biasanya saya lihat. Jenis orang tua yang pertama biasanya akan langsung membelikan mainan tersebut agar si anak bisa langsung diam dari tangisannya, dan tidak merepotkan orang tuanya. Dalam jangka panjang, sikap seperti ini akan membuat anak mempunyai karakter yang lemah, kurang tangguh, karena sudah dibiasakan diberi apa yang diinginkannya. Jenis orang tua yang kedua, biasanya akan menolak permintaan si anak dengan tegas, mungkin sambil memarahi atau mencuekkan begitu saja. Dalam jangka panjang, si anak akan mempunyai sifat yang acuh, kurang peduli dengan dirinya sendiri, kalau ditanya apa cita-cita atau keinginannya biasanya akan dijawab tidak tahu. Nah, anda sebagai orang tua bisa mencoba menambahkan alternatif pilihan ketiga, yaitu gabungan dari keduanya. Jadi saat seorang anak meminta sesuatu misalnya, kita bisa memberikannya dengan syarat tertentu (Hasanah 2017).

Sejak kecil, seorang anak perlu dididik tiga perilaku dasar dalam komunikasi dan berhubungan dengan orang lain. Pertama adalah harus belajar mengucapkan "terima kasih" kepada siapa saja yang sudah memberikan sesuatu kepadanya, kedua adalah harus belajar mengucapkan kata "tolong" apabila ingin meminta bantuan kepada orang di sekitarnya, dan ketiga adalah belajar mengucapkan kata "maaf" apabila memang bersalah. Kelihatannya memang sederhana, tapi coba lihat, berapa banyak orang yang merasa dirinya sudah dewasa yang terbiasa mengucapkan kata-kata tersebut. Karakter, kepribadian, dan kualitas seorang anak sangat ditentukan oleh pendidikan dan input yang diterimanya dari orang tua. Bila orang tua kurang memberikan bimbingan ini secara maksimal, maka peran ini akan diambil alih oleh lingkungan, yang mana bisa memberikan berbagai macam input yang lebih banyak negatifnya daripada positifnya. Kunci utama keberhasilan dalam membangun karakter positif pada anak adalah keteladanan dimana orang tua harus menjadi orang yang memiliki karakter positif. Perbuatan dan amal baik ini bukan hanya menjadi contoh nyata bagi anak tentang bagaimana karakter positif terwujudkan dalam segala sikap, perkataan dan perbuatan kita, tetapi juga menjadi penyemangat sekaligus untuk memudahkan anak kita dalam proses tumbuh kembangnya. Pembentukan karakter adalah sebuah perjalanan panjang dalam mendidik anak, hasilnya mungkin baru dapat kita lihat setelah proses berbulanbulan atau bahkan bertahun-tahun. Tidak pernah ada satu 'resep' mujarab yang dapat menjawab semua permasalahan dalam menanamkan karakter positif pada anak. Kesediaan untuk selalu belajar dan memperbaiki diri yang didasari kesadaran untuk menjadi teladan dan contoh yang baik bagi anak-anak kita adalah kunci keberhasilannya (Latifah 2020).

\section{KESIMPULAN}

Peran Orang Tua dalam Membentuk Karakter Anak Didik Melalui Bermain Peran yang berlangsung di Kelompok Bermain di TK A Khairin Islamic School Medan lain memiliki keterkaitan dan kesinambungan dalam proses sehingga pada akhirnya dapat memberikan kontribusi terhadap pengetahuan, sikap dan keterampilan anak dan orang tua anak. Menanamkan nilai-nilai karakter sejak usia dini merupakan tanggung jawab bersama antara orang tua, pendidik, pengasuh, masyarakat, dan pemerintah. Untuk itu kebersamaan, keselarasan, dan kemitraan dalam menanamkan nilai-nilai karakter sejak usia dini harus digalang dan dioptimalkan bersama. Disamping itu, Pendidik PAUD memiliki peran sangat besar dalam menjalankan peran selama proses pendidikan, pengasuhan, dan perlindungan bagi para peserta didik. Ketiga hal ini membuat para pendidik harus bekerja keras dibandingkan pendidik ditingkatan pendidikan lainnya. Mereka juga menjadi model atas sikap positif bagi peserta didiknya. Oleh sebab itu merupakan kewajiban bagi para pendidik untuk dapat memiliki karakter untuk menjalankan tugasnya serta berinteraksi dengan peserta didik, rekan sejawat, orangtua, serta lingkungan masyarakat yang dapat mendukung proses belajar. 
1167 Peran Orang Tua dalam Membentuk Karakter Anak Usia Dini di Taman Kanak-Kanak - Risky Ayu Permata

DOI: https://doi.org/10.31004/basicedu.v6i1.1969

\section{DAFTAR PUSTAKA}

Adpriyadi, Adpriyadi, And Sudarto Sudarto. 2020. "Pola Asuh Demokratis Orang Tua Dalam Pengembangan Potensi Diri Dan Karakter Anak Usia Dini." VOX EDUKASI: Jurnal Ilmiah Ilmu Pendidikan. Doi: 10.31932/Ve.V11i1.572.

Akhyadi, A. S., \&. Mulyono. 2018. "Program Parenting Dalam Meningkatkan Kualitas Pendidikan Keluarga." Abdimas Siliwangi.

Andhika, Muhammad Rezki. 2021. "Peran Orang Tua Sebagai Sumber Pendidikan Karakter Bagi Anak Usia Dini." At-Ta'dib: Jurnal Ilmiah Prodi Pendidikan Agama Islam. Doi: 10.47498/Tadib.V13i01.466.

Ansori, A., \&. Rosita. 2018. "T. Increasing Economic Capacity Of Rural Community Through The Use Of Local Ecological Potency Based." Journal Of Nonformal Education.

Astuti, Erni Puji. 2019. "Kontribusi Orang Tua Dalam Membangun Karakter Anak Sejak Usia Dini." Surya Abdimas. Doi: 10.37729/Abdimas.V3i1.505.

Dariah, Neneng. 2018. "Peran Orang Tua Dalam Membentuk Karakter Anak Usia Dini Melalui Bermain Peran (Study Kasus Di Kelompok Bermain Al-Munawar)." Comm-Edu (Community Education Journal). Doi: 10.22460/Comm-Edu.V1i3.1592.

Erzad, Azizah Maulina. 2018. "Peran Orang Tua Dalam Mendidik Anak Sejak Dini Di Lingkungan Keluarga." Thufula: Jurnal Inovasi Pendidikan Guru Raudhatul Athfal. Doi: 10.21043/Thufula.V5i2.3483.

Hasanah, Nur. 2017. "Peran Orang Tua Dalam Pendidikan Karakter Anak Usia Dini Melalui Ranah Afektif." Prosiding Seminar Nasional Tahunan Fakultas Ilmu Sosial Universitas Negeri Medan Tahun 2017.

Indrianti, Tia. 2020. "Peran Orang Tua Dalam Membentuk Karakter Anak Di Desa Kedaton Induk Kecamatan Batanghari Nuban Lampung Timur." Skripsi.

Irmalia, Septi. 2020. "Peran Orang Tua Dalam Pembentukan Karakter Anak Usia Dini." Jurnal El-Hamra (Kependidikan Dan Kemasyarakata).

Latifah, Atik. 2020. "Peran Lingkungan Dan Pola Asuh Orang Tua Terhadap Pembentukan Karakter Anak Usia Dini.” (JAPRA) Jurnal Pendidikan Raudhatul Athfal (JAPRA). Doi: 10.15575/Japra.V3i2.8785.

Miles, M. B., A. M. Huberman, And J. Saldana. 2014. Qualitative Data Analysis : A Methods Sourcebook. Thousand Oaks: SAGE Publication.

Nuraini, Fitria, And Toni Anwar Mahmud. 2020. "Peran Orang Tua Dalam Membentuk Karakter Anak Di Era Globalisasi Di Desa Masigit Kelurahan Citangkil Kota Cilegon.” Pro Patria: Jurnal Pendidikan, Kewarganegaraan, Hukum, Sosial, Dan Politik. Doi: 10.47080/Propatria.V3i2.973.

Pertiwi, Nunung Dian. 2021. "Peran Guru Dan Orang Tua Dalam Membentuk Karakter Jujur Pada Anak." Jurnal Pendidikan Dasar: Jurnal Tunas Nusantara.

Sabartiningsih, Mila, Jajang Aisyul Muzakki, And Durtam Durtam. 2018. "Implementasi Pemberian Reward Dan Punishment Dalam Membentuk Karakter Disiplin Anak Usia Dini." AWLADY : Jurnal Pendidikan Anak. Doi: 10.24235/Awlady.V4i1.2468.

Santika, Tika. 2018. "Peran Keluarga, Guru Dan Masyarakat Dalam Pembentukan Karakter Anak Usia Dini." JUDIKA (Jurnal Pendidikan UNSIKA).

Sari, Sri Yulia, And Nanang Nofriadi. 2019. "Pembentukan Karakter Pada Anak Usia Dini." SMART KIDS: Jurnal Pendidikan Islam Anak Usia Dini. Doi: 10.30631/Smartkids.V1i2.50.

Suryono, Ernie Martsiswati Dan Yoyon. 2014. "Peran Orang Tua Dan Pendidik Dalam Menerapkan Perilaku Disiplin Terhadap Anak Usia Dini." Jurnal Pendidikan Dan Pemberdayaan Masyarakat 1(2).

Ta’rifin, Ainurrafiq Dan A. 2005. Strategi Mendidik Anak Di Zaman Global. Jakarta: Grasindo.

Umar, Munirwan. 2015. "Peranan Orang Tua Dalam Peningkatan Prestasi Belajar Anak.” Jurnal Bimbingan 
1168 Peran Orang Tua dalam Membentuk Karakter Anak Usia Dini di Taman Kanak-Kanak - Risky Ayu Permata

DOI: https://doi.org/10.31004/basicedu.v6i1.1969

Konseling 1(1).

Yulianti, Dwi. 2010. Pendidikan Anak Usia Dini. Jakarta: Global Media. 